\title{
Adopting State Law as the Federal Rule of Decision: A Proposed Test
}

In Erie R.R. v. Tompkins, ${ }^{1}$ the Supreme Court removed the power of the federal courts to declare independent federal common law in deciding issues which would be governed by state law in state courts. Later cases have held, however, that where the matter before the court is closely related to a federal function, ${ }^{2}$ state law does not govern of its own force and the federal courts have the responsibility to fashion a federal rule to decide the issue. ${ }^{3}$ In Clearfield Trust Co. $v$. United States, ${ }^{4}$ the Court indicated that, unless Congress has specified otherwise, a federal court in this situation has the option either to "adopt" state law as the content of the federal rule or to develop uniform federal law ${ }^{5}$ to resolve the question. ${ }^{6}$

Since Clearfield, a body of case law has developed affirming and elaborating the availability of the choice to adopt state law. But a coherent standard for determining when to exercise this option has not emerged. A recent line of cases arising in the context of the Farmers Home Administration (FmHA) loan programs indicates the unsatisfactory state of the law on adoption. In suits by the Government against an auctioneer for the conversion of chattels on which the Government had a mortgage, the courts have had to determine whether the auctioneer's lack of knowledge of the mortgage is a defense against liability. Some circuits have adopted state law to resolve the issue, ${ }^{7}$ while others have used a uniform federal

304 U.S. 64 (1938).

2 See text and notes at notes 11-16 infra.

'See Mishkin, The Variousness of "Federal Law": Competence and Discretion in the Choice of National and State Rules for Decision, 105 U. PA. L. Rev. 797, 798-801 (1957). Judge Friendly has christened the law developed by federal courts in such situations the "new federal common law." Friendly, In Praise of Erie-And of the New Federal Common Law, 39 N.Y.U.L. REv. 383 (1964). The Supreme Court has suggested the term "law of independent federal judicial decision." United States v. Standard Oil Co., 332 U.S. 301, 308 (1947).

' 318 U.S. 363 (1943).

- Terminology in the adoption context tends to be confusing. The major terms, as used in this comment, are introduced in this note with references to notes providing further explanations. When an issue is substantially related to a federal program (see note 16 infra), the source of law (see note 9 infra) is federal, and the courts must fashion a federal rule to decide the issue. The content of this federal rule may be determined either by adopting state law or by developing or following uniform federal law on the issue.

- "In our choice of the applicable federal rule we have occasionally selected state law." 318 U.S. at 367.

7 United States v. Chappell Livestock Auction, Inc., 523 F.2d 840 (8th Cir. 1975); United States v. Union Livestock Sales Co., 298 F.2d 755 (4th Cir. 1962); United States v. Kramel, 234 F.2d 577 (8th Cir. 1956). 
law. ${ }^{8}$ These opposite results reached in virtually identical situations by courts purporting to apply the same criteria for determining whether to adopt state law indicate disagreement or confusion in interpreting these criteria.

In order to suggest improvements in the process of deciding whether to adopt state law, this comment first examines the policies involved in the decision and the criteria presently employed by the courts. An analysis and evaluation of these criteria leads to a proposed approach to the adoption question which resolves some of the confusion evident in present decisions. Finally, the proposed approach is applied to the FmHA cases to provide a concrete illustration of its operation.

\section{The Concept and Purpose of Adoption of State Law}

\section{A. Prerequisites for the Existence of the Adoption Issue}

Before a court can reach the issue of whether to adopt state law as the content of a federal rule in the case before it, the court must determine that the prerequisites for the adoption choice are present. First, the source ${ }^{9}$ of the law applicable to the litigation must be federal. ${ }^{10}$ Generally, the source of applicable law is held to be federal when the question involved in the litigation is substantially related to a federal governmental function. ${ }^{11}$ More specifically, a federal

${ }^{8}$ United States v. Carson, 372 F.2d 429 (6th Cir. 1967); United States v. Sommerville, 324 F.2d 712 (3d Cir. 1963), cert. denied, 376 U.S. 909 (1964); United States v. Matthews, 244 F.2d 626 (9th Cir. 1957); see United States v. Hext, 444 F.2d 804 (5th Cir. 1971); Cassidy Comm'n Co. v. United States, 387 F.2d 875 (10th Cir. 1967).

"The term "source" of law is a potentially confusing one and perhaps best defined by the method employed here, describing the situations in which courts have found a federal "source" of law. In these situations the federal interests are sufficiently involved to mandate that the question be governed by a federal rule of law, even though the court may still choose to adopt state law as the content of that federal rule.

10 See United States v. Little Lake Misere Land Co., 412 U.S. 580, $591-94$ (1973); Clearfield Trust Co. v. United States, 318 U.S. 363, 366-67 (1943); Mishkin, supra note 3, at 798801; cf. Friendly, supra note 3 at 410.

"Mishkin, supra note 3, at 801 . For criticism of the breadth afforded the concept of governmental functions and of the possible ramifications of this breadth under Clearfield, see Comment, Federal Jurisdiction-Choice of Law-Federal Law of Negotiable Instruments, 6 VILi. L. Rev. 388 (1961); 18 Tul. L. Rev. 152 (1943). See also Note, The Federal Common Law, 82 HARv. L. REv. 1512, 1526-29 (1969) (criticizing the use of the federal functions concept as a basis for choice of law).

The problem of adopting state law has arisen primarily in situations involving governmental functions, and this comment focuses on the adoption issue in this context. However, a recent case has suggested that state law may be considered in another context in which federal common law has been utilized, that of litigation by a state. Illinois v. City of Milwaukee, 406 U.S. 91, 107 (1972). This suggestion may reflect increased willingness to resort to state law in this area. Compare id. with Connecticut v. Massachusetts, 282 U.S. 660, 670 
source has been found in cases involving activities stemming from a treaty,,$^{12}$ a statute, ${ }^{13}$ or the Constitution; ${ }^{14}$ in cases involving a federal relationship $;^{15}$ and in cases arising out of a particular federal program. ${ }^{16}$

This first prerequisite removes a court's choice of law decision from the mandates of Erie ${ }^{17}$ and the Rules of Decision Act ${ }^{18}$ to apply state law. The reason for this effect is that when the source of law is federal, the rule of decision is federal; ${ }^{19}$ state law, even if adopted as the content of the federal rule, does not govern of its own force, ${ }^{20}$

(1931), and Kansas v. Colorado, 185 U.S. 125 (1902).

${ }_{12}$ Board of County Comm'rs v. United States, 308 U.S. 343, 349-50 (1939).

${ }^{13}$ E.g., Clearfield Trust Co. v. United States, 318 U.S. 363, 366-67 (1943).

"Id.

15 United States v. Standard Oil Co., 332 U.S. 301, 305-06 (1947) (relationship between a soldier and the federal government).

Is E.g., United States v. Little Lake Misere Land Co., 412 U.S. 580, 592 (1973). Unless used to refer to a specific federal program, the term "program" is used in this comment to encompass all activities of the Government which fall within the concept of federal function. The adoption issue usually arises in the context of a specific federal program, but more general federal matters also give rise to adoption questions, e.g., the government-soldier relationship in United States v. Standard Oil Co., 332 U.S. 301 (1947). However, the analysis involved in either case is the same.

17 Erie R.R. v. Tompkins, 304 U.S. 64 (1938); see United States v. Standard Oil Co., 332 U.S. 301, 309-10 (1947); Clearfield Trust Co. v. United States, 318 U.S. 363, 366 (1943); United States v. Chappell Livestock Auction, Inc., 523 F.2d 840, 841 (8th Cir. 1975); Mishkin, supra note 3, at 799.

18 The laws of the several states, except where the Constitution or treaties of the

United States or Acts of Congress otherwise require or provide, shall be regarded as rules of decision in civil actions in the courts of the United States, in cases where they apply. Judiciary Act of $1789, \S 34$, as amended, 28 U.S.C. $\S 1652$ (1970); see United States v. Little Lake Misere Land Co., 412 U.S. 580, 592-93 (1973); D'Oench, Duhme \& Co. v. FDIC, 315 U.S. 447, 465-75 (1942) (Jackson, J., concurring).

Although the Erie doctrine and the Rules of Decision Act are closely related, the Act may have a broader reach than the Erie principle. While it has been argued that Erie applies outside the context of diversity jurisdiction, see Hill, The Erie Doctrine in Bankruptcy, 66 HARv. L. REv. 1013, 1031-36 (1953), it has generally been limited to diversity situations. See D'Oench, Duhme \& Co. v. FDIC, 315 U.S, 447, 465-68, 471-72 (1942) (Jackson, J., concurring); C. Wright, The Law of Feneral Courts 241-53 (2d ed. 1970). The Rules of Decision Act is relevant outside the diversity area. See Note, Rules of Decision in Nondiversity Suits, 69 YALE L.J. 1428, 1431 (1960). It has also been suggested that although Erie interpreted the Rules of Decision Act, the decision in Erie might not completely coincide with all the dictates of the Act. See Note, Clearfield: Clouded Field of Federal Common Law, 53 Cozum. L. Rev. 991, 993-95 (1953).

" See United States v. Standard Oil Co., 332 U.S. 301, 305 (1947); Clearfield Trust Co. v. United States, 318 U.S. 363, 366-67 (1943); Sola Elec. Co. v. Jefferson Elec. Co., 317 U.S. 173,176 (1942). The source of the law, not the statutory basis for federal jurisdiction, determines the nature of the governing rule. Sola Elec. Co. v. Jefferson Elec. Co., 317 U.S. 173, 176 (1942) (diversity case in which a federal source of law necessitated a federal rule).

${ }^{20}$ See Board of County Comm'rs v. United States, 308 U.S. 343, 351-52 (1959); P. Bator, P. Mishkin, D. Shapiro, \& H. Wechsler, The Federal Courts and the Federal System 768 (2d ed. 1973); Hart, The Relations between State and Federal Law, 54 Colum. L. Rev. 489, 
but only by virtue of its incorporation as the federal law. Erie can be interpreted as holding that where state law governs an issue of its own force, it is to be applied regardless of the forum in which the issue is litigated. ${ }^{21}$ Where the source of law is federal, state law does not govern of its own force, and Erie is therefore inapposite. ${ }^{22}$ The rationale for holding that the Rules of Decision Act's command to use state law does not apply is similar: when the source of law is federal, Congress or the Constitution " 'require[s]' otherwise than that state law [should] govern of its own force."23

The second prerequisite for reaching the adoption issue is that Congress must not have determined the choice of law issue, ${ }^{24}$ either by dictating the use of state or federal law ${ }^{25}$ or by providing the specific substantive law to be followed. ${ }^{26}$ Taken together, these two prerequisites ${ }^{27}$ set the stage for the adoption choice by requiring the

529 (1954). Since the resulting rule is federal, it will be binding on the states as federal law. See Cullison, State Courts, State Law, and Concurrent Jurisdiction of Federal Questions, 48 Iowa L. Rev. 230, 235 (1963); Hart, supra, at 507; Hill, The Law-Making Power of the Federal Courts: Constitutional Preemption, 67 Colum. L. REv. 1024, 1073-74 (1967). For discussion of the problems of ascertaining state law in federal courts and federal law in state courts, see text and notes at notes 33-34 infra.

${ }^{21}$ Mishkin, supra note 3, at 798-800.

${ }^{22}$ See United States v. Standard Oil Co., 332 U.S. 301, 309-10 (1947); Clearfield Trust Co. v. United States, 318 U.S. 363, 366-67 (1943); United States v. Chappell Livestock Auction, Inc., 523 F.2d 840, 841 (8th Cir. 1975); Mishkin, supra note 3, at 799-800. The fact that Erie is not applicable to the adoption issue affects both the methods by which state law is adopted and the effect adoption has on other courts. See Mishkin, supra note 3, at 802-10; Note, The Competence of Federal Courts to Formulate Rules of Decision, 77 HaRv. L. REv. 1084,1099 (1964). One commentator has stated that the Erie decision itself, by leaving to the states the areas of law where they should exercise authority, led to the development of areas, such as those connected with the adoption issue, in which state law is not mandated. Friendly, supra note 3 , at $405-12$.

${ }^{23}$ United States v. Little Lake Misere Land Co., 412 U.S. 580, 592-93 (1973); see D’Oench, Duhme \& Co. v. FDIC, 315 U.S. 447, $465-75$ (1942) (Jackson, J., concurring); Note, The Competence of Federal Courts to Formulate Rules of Decision, 77 HaRv. L. REv. 1084, 1095-96 (1964); 49 N.C.L. Rev. 358, 360-61 (1971). For criticism of this approach as applied in the early adoption cases, on the ground that the mere federal source of law is insufficient to invoke exceptions to the Rules of Decision Act, see Note, Clearfield: Clouded Field of Federal Common Law, 53 Colum. L. Rev. 991, 997-1008 (1953). For alternative constructions of the application of the Rules of Decision Act, emphasizing a restrictive approach to judicial creation of uniform federal law, see Mishkin, supra note 3, at $814 \mathrm{n} .64$; Note, Rules of Decision in Nondiversity Suits, 69 YALE L.J. 1428, 1449 (1960); 49 N.C.L. REv. 358, 365-66 (1971).

${ }_{24}$ See, e.g., Clearfield Trust Co. v. United States, 318 U.S. 363, 367 (1943); Board of County Comm'rs v. United States, 308 U.S. 343, 349 (1939). See also Moor v. County of Alameda, 411 U.S. 693, 701-02 n.12 (1973). Legislative nonspecification may, of course, indicate either that Congress was oblivious to the possible problem, or that it did not consider the state and federal interests involved sufficiently strong to merit congressional concern.

${ }_{25}$ United States v. Little Lake Misere Land Co., 412 U.S. 580, 593 (1973).

${ }^{26}$ Board of County Comm'rs v. United States, 308 U.S. 343,349 (1939).

${ }^{27}$ In considering the prerequisites for the adoption issue, it should be noted that it is not necessary for the Government to be a party to the suit. See Mishkin, supra note 3, at 801 


\section{courts to fashion a federal rule while leaving them free from any mandate to base that rule on either federal or state law. ${ }^{28}$}

\section{B. Consequences of Choosing to Adopt State Law}

The result of adopting state law as the content of a federal rule is that when the same issue arises in other states, the laws of those states will provide the basis for decision. ${ }^{29}$ Thus a variety of state laws will be used, each law serving as the content of the federal rule in its own forum..$^{30}$ If a state law should change after being adopted

n.19. Suits between private parties have given rise to the adoption issue when the activity involved in the litigation was governed by a federal statute. E.g., Wallis v. Pan Am. Petroleum Corp., 384 U.S. 63 (1966); Sola Elec. Co. v. Jefferson Elec. Co., 317 U.S. 173 (1942). However, where the Government is a party, there is a greater likelihoood that a federal function will be involved and therefore that an adoption issue will arise. See United States v. Little Lake Misere Land Co., 412 U.S. 580, 592-93 (1973).

It should also be noted that the possibility of adoption may arise in both diversity and nondiversity cases. Dumbauld, The Clear Field of Clearfield, 61 Dick. L. REv. 299, 301 (1957); see, e.g., Wallis v. Pan Am. Petroleum Corp., 384 U.S. 63 (1966) (diversity case); Sola Elec. Co. v. Jefferson Elec. Co., 317 U.S. 173 (1942) (diversity case); Clearfield Trust Co. v. United States, 318 U.S. 363 (1943) (nondiversity case).

${ }^{2 \times}$ The adoption doctrine involves several considerations similar to the preemption doctrine. Preemption analysis seeks to determine whether Congress has indicated an intent to occupy the area of law in question; if it has, or if simultaneous operation of state law would create a conflict with federal law, the state law is displaced. See generally Note, The Preemption Doctrine: Shifting Perspectives on Federalism and the Burger Court, 75 CoLcM. L. REv. 623 (1975). Adoption is also concerned with congressional intent and federal-state conflict, but the adoption issue arises not when there are both state and federal laws on the issue in question, but when a state law of general applicability is considered as a means of determining an issue on which Congress is silent. While the presence of congressional intent to occupy the area of law is one ground for preemption, the absence of any congressional intent is one of the prerequisites for the existence of the adoption issue. The effect of a conflict in the preemption context is that the federal law prevails under the supremacy clause, and the state law is therefore superseded; conflict in the adoption context means merely that otherwise valid state law will not apply to resolve the particular federal law issue. Compare, e.g., Schwegmann Bros. v. Calvert Distilling Corp., 341 U.S. 384 (1951) (preemption), with United States v. Little Lake Misere Land Co., 412 U.S. 580 (1973) (nonadoption). There have been some parallel developments in these two doctrines, however. Recent preemption cases exhibit tendencies similar to those in some adoption decisions. Greater recognition has been accorded state interests absent express congressional concern, "trivial" conflicts have not served to nullify state laws, and courts have become less inclined to find overwhelming national interests in particular policies. See Note, The Preemption Doctrine: Shifting Perspectives on Federalism and the Burger Court, supra, at 642, 647, 653. See also Kohr v. Allegheny Airlines, Inc., 504 F.2d 400 (7th Cir. 1974), cert. denied, 421 U.S. 978 (1975) (preemption-type analysis used to determine the existence of a federal source of law).

29 See United States v. Yazell, 382 U.S. 341, 356-57 (1966); Mishkin, supra note 3, at 802. In each case, the state law adopted must not conflict with the interests of the federal program. See United States v. Little Lake Misere Land Co., 412 U.S. 580, 594-96 (1973); De Sylva v. Ballentine, 351 U.S. 570, 580-81 (1956).

to The effect of adoption may resemble the result under Erie or the Rules of Decision Act; yet there are important differences between these latter grounds for recourse to state law and adoption. As Professor Mishkin notes, state law is adopted only with reference to particular 
to resolve a particular issue, the new law will generally be employed as the content of the governing federal rule in the particular state. ${ }^{31}$

The diversity of state laws and the need to define the federal rule by reference to the law of each forum state give rise to several problems. If two or more states are involved in the activity under litigation, a court must decide which state's law applies. In the adoption context, commentators have argued that Erie and its progeny do not control the determination of this issue and that courts are therefore free to develop federal choice of law principles. ${ }^{32} \mathrm{An}$ other problem created by a decision to adopt state law is that federal courts must ascertain the relevant state law. ${ }^{33}$ However, this is a familiar task for federal courts, since they frequently are required to identify state law in such contexts as diversity litigation. Any difficulties in determining the state law for adoption purposes are susceptible to resolution by methods similar to those used in other contexts. ${ }^{34}$

issues, while under the Erie doctrine state law must govern the entire litigation (absent a federal question). Second, only state law that does not conflict with the goals of the federal program can be adopted, while under Erie, valid state law is applicable without reference to its content. Mishkin, supra note 3, at 804-06. The Supreme Court seems to have accepted Mishkin's general rationale and to have reached the result he suggested for cases involving conflict between a state's law and a federal program. See United States v. Little Lake Misere Land Co., 412 U.S. 580 (1973).

${ }^{31}$ See United States v. Big Z Warehouse, 311 F. Supp. 283, 286 (S.D. Ga. 1970). Again, however, the changed state law must not be considered aberrant or hostile, that is, in conflict with the interests of the federal program.

${ }^{32}$ In the adoption context, the inapplicability of Erie means that the principle, announced in Klaxon Co. v. Stentor Elec. Co., 313 U.S. 487, 496 (1941), that Erie requires federal courts to use the conflicts of laws rules of the forum state, does not apply. Since the law to be fashioned is federal, courts should be free to develop their own principles for choosing between state laws. See Hart, supra note 20, at 536; Mishkin, supra note 3, at 80608. See generally Note, Applicability of State Conflicts Rules when Issues of State Law Arise in Federal Question Cases, 68 HaRv. L. REv. 1212 (1955). For a suggested approach to developing choice of law principles for adoption, see Mishkin, supra note 3, at 806-08.

${ }^{33}$ Since state courts have concurrent jurisdiction of the major heads of federal jurisdiction, see Cullison, supra note 20, at 240 ; Hart, supra note 20 , at 533 , and since subsidiary federal issues may be involved in state-created claims, see Hart, supra note 20, at 537, adoption might also require state courts to ascertain federal law relevant to the question of whether state law should be adopted. In such cases, the applicable federal law, however developed, is binding on state courts. See note 20 supra. For a suggested approach to this problem see Comment, The State Courts and the Federal Common Law, 27 ALBany L. REv. 73 (1963).

34 See Bernhardt v. Polygraphic Co. of America, 350 U.S. 198 (1956); Note, Federal Interpretation of State Law-An Argument for Expanded Scope of Inquiry, 53 MinN. L. REv. 806 (1969). One difference between problems of ascertaining state law under Erie and under adoption is that once it is clear that state law governs under Erie, the state law must be determined, despite the difficulties involved (or prophecy required). In contrast, although the content of existing state law is relevant in every adoption case, since this content must be known in order to determine whether there is a conflict with the operation of the federal 


\section{Rationale of the Adoption Option}

Allowing courts the option to adopt state law as the content of a federal rule comports with both the realities of federal action and the coordinate existence of state and federal law. The federal system of government does not seek a comprehensive, nationally uniform body of law. The recognized value of permitting local and possibly diverse solutions to the problems of regulating conduct ${ }^{35}$ is reflected in the considerable latitude allowed states in ordering the affairs of their citizens. ${ }^{36}$ State law plays a significant role even in areas for which federal law has been developed..$^{37}$ Federal regulation is often interstitial in nature, enacted against a background of state law and building on state law relationships. ${ }^{38}$ When used in conjunction with this interstitial federal law, state law provides a vehicle for effectuating the federal law and integrating it into the rules of conduct already governing in various localities. ${ }^{39}$

Whenever the prerequisites for reaching the adoption issue are present, there exist both a federal interest in effectively implementing the federal program and a state interest in preserving existing state regulation of the area in which the federal action takes place. Neither of these interests in the abstract has been held legally sufficient to mandate recourse exclusively to either state or federal law. While the involvement of a substantial federal governmental function determines that the source of the applicable law will be federal, it does not dictate automatic use of a uniform federal law..$^{40}$ State law does not govern of its own force where the source of law is federal and therefore will not necessarily be applied. The refusal of the courts to mandate exclusive use of federal or state law in the adoption context indicates a recognition of the desirability of accommodating state and federal interests. Achieving this accommodation thus appears to be the general purpose of the adoption option. This purpose suggests that the essence of a proper test to determine whether to adopt state law is a balancing of the impact on state

program, a finding that state law does not exist on the issue or is not easily determinable may be sufficient to preclude adoption. In such situations, the state interest in avoiding dislocations to state activities is not present and no convenient source of decision is provided, so the purposes of adoption would not be served by adopting state law.

35 See Hart, supra note 20, at 539-42.

"Cf. Nebbia v. New York, 291 U.S. 502 (1934).

${ }^{37}$ See Hart, supra note 20, at 525-35; Mishkin, supra note 3, at 810-11.

* Hart, supra note 20, at 525, 535; Mishkin, supra note 3, at 811; Wechsler, The Political Safeguards of Federalism: The Role of the States in the Composition and Selection of the National Government, 54 Colum. L. Rev. 543, 544-45 (1954).

" Hart, supra note 20, at 534-35, 542 .

to United States v. Little Lake Misere Land Co., 412 U.S. 580, 592-94 (1973). 
interests resulting from federal displacement of state law against the degree to which adopting state law would affect operation of the federal program."1 This balancing approach must, however, be qualified by the fundamental purpose of the adoption option: providing a means to implement programs of the federal government. ${ }^{42}$ Thus a direct conflict between the state law in question and the operations of the federal program must preclude adoption of state law. ${ }^{43}$

\section{Development of the Major Criteria}

Courts have developed three major criteria for determining whether state law should be adopted: the need for uniformity in operating the federal program, the presence of an area of traditionally local concern, and the existence of conflict between the state law and the federal program. When a court discovers a conflict between the state law and the federal program, this often proves conclusive. Absent a conflict, courts generally balance the state and federal interests represented by the other two criteria either by expressly weighing these interests or by implicitly doing so through evaluating only one of these criteria and finding it determinative in the particular case. An examination of three major cases dealing with the adoption issue-Clearfield Trust Co. $v$. United States, ${ }^{44}$. United States v. Standard Oil Co. ${ }^{45}$ and United States v. Little Lake Misere Land $\mathrm{Co}^{46}$-illustrates the content of the three criteria and their roles in a court's determination whether to adopt state law.

The substantive issue in Clearfield ${ }^{47}$ was whether the defense of laches could defeat a claim by the United States against a trust company which had collected on a fraudulently endorsed Works Progress Administration paycheck. The check had not reached the person to whom it was issued but had been endorsed and cashed by an unknown individual. Ultimately Clearfield Trust collected on the check from a Federal Reserve Bank. Although agents of the United

"See United States v. View Crest Garden Apts., Inc., 268 F.2d 380, 383 (9th Cir. 1959), cert. denied, 361 U.S. 884 (1959).

$\$ 2$ See United States v. Little Lake Misere Land Co., 412 U.S. 580, 594-601 (1973); United States v. Standard Oil Co., 332 U.S. 301, 309-11 (1947).

13 See, e.g., RFC v. Beaver County, 328 U.S. 204, 208, 210 (1946). The supremacy clause might require this result. See United States v. County of Allegheny, 322 U.S. 174, 182-83 (1944).

" 318 U.S. 363 (1943).

45332 U.S. 301 (1947).

16412 U.S. 580 (1973).

${ }_{17} 318$ U.S. 363 (1943). For further discussion of Clearfield, see Dumbauld, supra note 27; 43 Colum. L. Rev. 520 (1943); 75 HaRv. L. Rev. 1656 (1962); 18 IND. L.J. 311 (1943). 
States had almost immediate knowledge that the check had not been received by the proper party, the Government did not notify Clearfield Trust promptly about the forgery and procrastinated in requesting reimbursement. Eventually, the United States sued Clearfield Trust on its express guaranty of prior endorsements to recover the amount of the check.

The Supreme Court found that the source of the law governing the cause of action was federal because the check had been issued by the Government for services performed under a federal statute. ${ }^{48}$ The issue then became whether to use a uniform federal law or to adopt state law, under which the Government's unreasonable delay in giving notice would have been a defense for Clearfield Trust. Noting that the United States used commercial paper on a vast scale and often in transactions conducted in several states, ${ }^{49}$ the Court concluded that adopting state law would lead to undue diversity and uncertainty in determining the rights and duties of the Government in such transactions. ${ }^{50}$ The need for uniformity of result in order to ease administration of the federal program was found to justify the use of a uniform federal law.

The Court's reliance on the alleged need for uniformity has been heavily criticized..$^{51}$ Both the specific holding of Clearfield and its strong emphasis on uniformity for administrative ease have been limited by later Supreme Court decisions. ${ }^{52}$ The enduring impor-

1* Clearfield Trust Co. v. United States, 318 U.S. 363, 366 (1943).

s9 The existence of these multistate transactions raised the prospect, considered undesirable by the Court, that the adoption of state law might generate conflict of laws issues. Id. at 367 .

so $I d$.

st These criticisms generally emphasize that uniformity was not necessary to prevent significant impairment of the federal program and that the uniformity argument therefore served primarily to provide the Government with an unwarranted edge in litigation to which it is a party. See Mishkin, supra note 3, at 828-32; Note, The Federal Common Law, 82 Harv. L. Rev. 1512, 1529-31 (1969). The uniformity argument utilized in Clearfield seems to be essentially an ease of administration argument: the Court appeared to be concerned with administrative difficulties and never suggested that there was a direct conflict between the use of state law and the continued issuance of commercial paper. The diversity of results which would ensue would not appear sufficiently serious to conflict with the continued federal use of commercial paper. Indeed, it has been emphasized that large corporations face, and cope with, similar problems of diversity in their commercial practices. See Note, The Federal Common Law, 82 HaRv. L. Rev. 1512, 1530 (1969). But see 18 U. PITT. L. Rev. 820, 823 (1957) (suggesting that the federal activity might have been significantly affected by diverse results, since uncertainty might have impaired the negotiability of commercial paper).

s2 The general holding that suits involving federal commercial paper would be determined by uniform federal law was limited in Bank of America v. Parnell, 352 U.S. 29 (1956), which held that suits among private parties involving federal commercial paper would be governed by state law since the utilization of state law in such circumstances did not have a direct adverse effect on the rights and duties of the United States. See Dumbauld, supra 
tance of Clearfield lies in its specific recognition of the possibility of adopting state law $^{53}$ and in its reliance on uniformity as one criterion to be considered in deciding whether to adopt state law. ${ }^{54}$

In Standard Oil,,$^{55}$ the Government sought to establish its right to recover from one who had injured a serviceman the amount the Government had spent on the victim's hospitalization and wages. One issue in the case was whether the existence of this cause of action would be determined by adopting state law or using a uniform federal law. The Supreme Court found a federal source for the governing rule in the federal relationship existing between the Government and the soldier and further supported this finding by noting the involvement of federal fiscal powers in the litigation..$^{56}$

In determining whether to adopt state law as the content of the federal rule, the Court first described several situations where adoption would be appropriate. First, adopting state law would be proper when the Government has placed itself in a position where its rights are necessarily determined by reference to state law, or when Congress has presumably consented to the use of state law by not providing otherwise in legislating for areas ordinarily governed by state law. ${ }^{57}$ These two considerations can be seen as referring to the presence of areas of traditionally local concern as a criterion for adoption. ${ }^{58}$ Second, state law might be adopted when it provides a convenient solution that is not inconsistent with adequately protecting the federal interests involved. ${ }^{59}$ Finally, adopting state law may be appropriate when adoption would not result in substantially diverse

note 27 , at $310,316-21$; Mishkin, supra note 3 , at 833 . In addition, the strong reliance on uniformity for ease of administration seems to have been limited by the growing tendency of the Court to examine the need for uniformity more closely within the circumstances of the particular case. See Johnson v. Railway Express Agency, Inc., 421 U.S. 454(1975); United States v. Little Lake Misere Land Co., 412 U.S. 580, 607 (1973) (Rehnquist, J., concurring); UAW v. Hoosier Cardinal Corp., 383 U.S. 696 (1966).

${ }^{33}$ State law had previously been adopted as providing the content for a federal rule in Royal Indem. Co. v. United States, 313 U.S. 289 (1941), and Board of County Comm'rs v. United States, 308 U.S. 343 (1939).

54 See Mishkin, supra note 3, at 831-33.

55 United States v. Standard Oil Co., 332 U.S. 301 (1947). For further discussion of the Standard Oil case, see Lenhoff, On Interpretative Theories: A Comparative Study in Legislation, 27 Texas L. REv. 312 (1949); Note, Federal Practice: The Rebirth of Federal Law, 34 Cornell L.Q. 110 (1948); 28 Boston U.L. Rev. 83 (1948); 36 Geo. L.J. 89 (1947); 27 NeB.

L. REv. 461 (1947); 26 TEXas L. REv. 353 (1948).

${ }^{56} 332$ U.S. 301, 305-06 (1947).

${ }^{57} \mathrm{Id}$. at 308-09.

ss The Court used the example of title to real estate for the first consideration; for the second, the Court cited RFC v. Beaver County, 328 U.S. 204 (1946), which adopted state law, relying heavily on the fact that the area of law in question-real property law-had been traditionally governed by state law.

59 332 U.S. 301, 309 (1947). 
treatment of an issue which should be treated uniformly.$^{60}$ These considerations suggest two additional criteria: the absence of a conflict between state law and federal interests, and the need for uniformity. The Court's review of these situations suggests that state law is properly adopted when it would provide a convenient solution and would not lead to inconsistencies or undesirable diversity.

In deciding the issue before it, however, the Court seemed to reverse its emphasis and to demand more affirmative reasons for adopting state law. The Court held that a uniform federal law should govern in Standard Oil because there was no affirmative justification for diversity of results, because the issue concerned did not involve particularly local concerns, and because a uniform rule was ordinarily more appropriate in handling federal fiscal matters. ${ }^{61}$

The issue in Little Lake $e^{62}$ was whether state statutory law, which provided a retroactive rule of imprescriptibility of mineral rights, would be adopted to govern federal acquisitions of land in the state under the Migratory Bird Conservation Act. ${ }^{63}$ The contract and condemnation judgment by which the United States had acquired the lands in question reserved mineral rights to the prior owners under a ten-year rule of prescription. According to the reservation provisions, the mineral rights had vested in the Government; but a state statute passed three years after the contract and a year after the condemnation judgment provided that the rights reserved in such situations would be imprescriptible.

Since the land acquisition arose from and was related to a federal regulatory program, the Court found that the source of the law was federal..$^{64}$ In considering the adoption issue the Court decided against adopting state law in the case before it, but seemed to leave open the possibility of adopting state law to resolve the same issue in other states. Rather than holding that a uniform federal law must be formulated to govern federal land acquisitions, the Court held that even if state law might generally be adopted in connection with these transactions, the particular state law at issue could not be adopted because it was hostile to the interests of the federal program. ${ }^{65}$ The state statute was found to be hostile because it would

${ }^{60}$ Id.

61 Id. at 310-11.

62 United States v. Little Lake Misere Land Co., 412 U.S. 580 (1973). For further discussion of Little Lake, see Sachse, United States v. Little Lake Misere Land Co.-A Choice of Law, 34 LA. L. Rev. 29 (1973); 59 A.B.A.J. 1441 (1973).

(s) 16 U.S.C. $\$ \S 715-715 \mathrm{~s}(1970)$.

b4 412 U.S. 580 , 592-94 (1973).

${ }^{65}$ Id. at 595-97; see De Sylva v. Ballentine, 351 U.S. 570, 581 (1956); United States v. Albrecht, 496 F.2d 906 (8th Cir. 1974). 
have conflicted with the purposes of the federal program by depriving the Government of its contractual interests and thereby creating uncertainty in land transactions under the Act. ${ }^{66}$ Little Lake's focus on the conflict criterion and its suggestion that even if the particular state law in question conflicts with the federal program, other nonconflicting state laws might be adopted ${ }^{67}$ may indicate a move away from the strong emphasis on uniformity evident in Clearfield, and to some degree in Standard Oil, and a departure from the presumption in favor of using uniform federal law which often accompanies that emphasis.

\section{A Proposed Test for Adoption of State Law}

The development of the three major criteria in these cases-the need for uniformity in operating the federal program, the presence of an area of traditionally local concern, and the existence of a conflict between the state law and the federal program-demonstrates an attempt to specify the state and federal interests relevant to determining whether state law should be adopted..$^{68}$ Courts, however, seldom carefully analyze these criteria and have often failed to apply them systematically in particular cases. ${ }^{69}$ Specific aspects of the broad concepts embodied in each criterion are not examined to identify those relevant to a given case. ${ }^{70}$ The weight accorded to each major criterion and to the specific aspects of each criterion involved in a particular case is seldom determined in light of the purpose of the adoption option. Often courts seriously examine only one criterion, thereby determining the result through initial selection of which criterion is to be deemed significant in the particular case. ${ }^{71}$

66412 U.S. 580, 596-99 (1973).

${ }^{67}$ See De Sylva v. Ballentine, 351 U.S. 570 (1956).

${ }^{68}$ With the addition of the state interest in avoiding the general disruptive effects that would be caused by using federal law to govern aspects of activities normally regulated by state law, see p. 843 infra, these three criteria seem to represent the federal and state interests to be considered in determining whether state law should be adopted. The purpose of the adoption option is to balance the state and federal interests affected in the context of furthering a federal program. These three criteria represent the major direct effects on the state and federal interests which would result if the option were or were not exercised.

${ }^{63}$ The Supreme Court has recently begun to analyze these criteria more thoroughly. See United States v. Little Lake Misere Land Co., 412 U.S. 580 (1973) (conflict); UAW v. Hoosier Cardinal Corp., 383 U.S. 696 (1966) (uniformity). But failure to analyze the criteria remains characteristic of the majority of circuit courts. The series of FmHA cases discussed in text and notes at notes 133-74 infra illustrates this circuit court approach.

${ }^{70}$ See, e.g., Clearfield Trust Co. v. United States, 318 U.S. 363 (1943); cases cited notes 7,8 supra.

${ }^{71}$ See, e.g., Clearfield Trust Co. v. United States, 318 U.S. 363 (1943); United States v. 
The failure to analyze the content and weight of the criteria and to apply them systematically allows courts great discretion in deciding whether to adopt state law, a discretion uninformed by the purpose of accommodating the state and federal interests involved in the operation of a federal program. Decisions resulting from the exercise of this discretion carry no assurance that a proper determination of whether state law should be adopted has been made. In practice, this approach has frequently contributed to an unjustified presumption in favor of a uniform federal law. ${ }^{72}$ Analyzing the content of each of the three major criteria and considering the weight that should be attached to the general criteria and their specific aspects in light of the purpose of the adoption option provides the foundation necessary to design a more satisfactory approach to the adoption question.

\section{A. The Conflict Criterion}

Courts considering adoption issues have generally agreed that a finding of conflict between applying state law and effectuating a federal program will preclude the adoption of state law. ${ }^{73}$ The decisions indicate that a conflict exists when using state law would virtually nullify a particular activity or purpose of the federal program involved. A conflict has been found when adopting state law would have effectively terminated contractual interests obtained under a federal program ${ }^{74}$ or would have defeated the specific purpose for which the Government had entered into a transaction under a federal program. ${ }^{75}$ Conflict also exists when adopting state law would result in evading the dictates of a federal program. ${ }^{76} \mathrm{~A}$ con-

Hext, 444 F.2d 804, 808-09 (5th Cir. 1971); Cassidy Comm'n Co. v. United States, 387 F.2d 875, 878-79 (10th Cir. 1967). If the single criterion examined is the conflict criterion, and if a conflict is found, the preeminent purpose of effectuating the federal program would support rejecting state law without considering other criteria. In any other situation, the policy of accommodating state and federal interests requires that the interests represented by all the other criteria be considered and weighed.

${ }^{72}$ E.g., Clearfield Trust Co. v. United States, 318 U.S. 363 (1943); see note 51 supra.

73 See Wallis v. Pan Am. Petroleum Corp., 384 U.S. 63 (1966); RFC v. Beaver County, 328 U.S. 204 (1946); Sola Elec. Co. v. Jefferson Elec. Co., 317 U.S. 173 (1942); Royal Indem. Co. v. United States, 313 U.S. 289 (1941).

7 United States v. Little Lake Misere Land Co., 412 U.S. 580 (1973); see United States v. Albrecht, 496 F.2d 906 (8th Cir. 1974).

${ }^{75}$ United States v. County of Allegheny, 322 U.S. 174 (1944).

7t This notion shades into an argument of discrimination against the federal government as an alternative ground for holding that state law is inapplicable. Such an argument was made by Justice Rehnquist in his concurring opinion in Little Lake. 412 U.S. at 606. The majority did not discuss this argument, but seemed to suggest that if legitimate state interests opposed to those of the federal government were present, the state law would not be automati- 
flict has been found, for example, when adopting state law would have allowed persons to avoid the liability imposed by a federal statute $^{77}$ and when the state law was primarily designed to thwart a federal cause of action. ${ }^{78}$

Courts occasionally use other terminology to express the conflict concept. In some cases, particularly when the area of law in question has been one of traditionally local concern, courts have refused to adopt state law they found "aberrant or hostile."79 This standard seems functionally equivalent to the conflict criterion..$^{80}$ The heart of the "hostility" test as applied to the particular state law involved is an examination of possible conflicts with federal interests; ${ }^{81}$ the test for aberrance may reflect the assumption that the farther a state law moves away from a generally accepted law, the greater the potential for conflict with the interests of the federal program becomes. ${ }^{82}$

Some cases have defined the standard for adoption of state law in terms of "inconsistency" with the interests of the federal pro-

cally disqualified on discrimination grounds and that such a situation would be more properly analyzed in terms of the conflict criterion. Id. at 599-601. Justice Rehnquist's discrimination argument seems to be limited to state statutes actually directed against particular activities of the federal government, while the conflict criterion is used to analyze state laws effecting the evasion of liabilities under federal statutes. See Sola Elec. Co. v. Jefferson Elec. Co., 317 U.S. 173 (1942); Edgerton v. Puckett, 391 F. Supp. 463 (W.D. Va. 1975).

" Sola Elec. Co. v. Jefferson Elec. Co., 317 U.S. 173 (1942).

78 Edgerton v. Puckett, 391 F. Supp. 463 (W.D. Va. 1975).

7 E.g., United States v. Little Lake Misere Land Co., 412 U.S. 580 (1973); see De Sylva v. Ballentine, 351 U.S. 570 (1956).

${ }^{80}$ See, e.g., United States v. Little Lake Misere Land Co., 412 U.S. 580 (1973). In determining not to adopt an "aberrant or hostile" state law, the Court used the terms "hostile" and "conflicting" as functional equivalents. Rather than defining a distinct notion of hostility or comparing the law in question with other state laws to determine aberrancy, the Court emphasized the harm to the federal program which would result from the plain discordance between the law and the federal program. Id. at 597, 604. While the Court thus used a conflict standard in dealing with the specific state law in question, its use of the phrase "aberrant or hostile" could be viewed as preserving the possibility that in future cases involving the same issue the laws of other states could be adopted. See also United States v. Albrecht, 496 F.2d 906 (8th Cir. 1974).

${ }^{81}$ See United States v. Little Lake Misere Land Co., 412 U.S. 580 (1973); United States v. Albrecht, 496 F.2d 906 (8th Cir. 1974); United States v. O'Connell, 496 F.2d 1329 (2d Cir. 1974).

${ }_{82}$ See De Sylva v. Ballentine, 351 U.S. 570, 581 (1956), where the Court emphasized the possibility of disqualifying a particular state's law that defines a relationship in "a way entirely strange to those familiar with its ordinary usage." Id. at 581. For, as the state usage becomes more unusual, the possibility that it would conflict with the purpose of the federal program becomes larger. See id. at 582. This does not, of course, mean that an unusual law should be disqualified for adoption; divergence from the norm merely suggests the possibility of conflict. 
gram. ${ }^{83}$ The concept of inconsistency has not been developed since the facts involved in the major cases relying on this standard were found to present no inconsistency ${ }^{84}$ The use of the terms "conflict" and "inconsistency" by the courts has been imprecise, and no significance has been attached to this difference in terminology. ${ }^{85}$ Further, the Supreme Court's analysis in Johnson v. Railway Express Agency, Inc. ${ }^{86}$ affirmatively supports the conclusion that "inconsistent" and "conflicting" describe the same standard. In that case the issue was whether to adopt a short (one-year) state statute of limitations for section 1981 of title 42 of the United States Code, which, inter alia, creates a cause of action against racially discriminatory contract requirements. ${ }^{87}$ The Court acknowledged that adopting the state law could detrimentally affect the federal legislative scheme, but chose to use the state law because no actual conflict was discovered. ${ }^{88}$ In the opinion the Court spoke of the state law as both not "inconsistent" and not in "conflict" with the federal plan. ${ }^{89}$ The definition of the term conflict, ${ }^{90}$ the use of precedent, ${ }^{91}$ and the result reached ${ }^{92}$ indicate adherence to a conflict standard.

A finding of conflict precludes the adoption of state law $w^{93} \mathrm{de}$ spite the weight of any of the other criteria involved in considering whether to exercise the adoption option. ${ }^{94}$ This result is consonant with the purpose of the option to adopt state law. Since the fundamental purpose of the adoption option is to provide a means for implementing federal governmental programs, state law which di-

s See, e.g., United States v. Standard Oil Co., 332 U.S. 301 (1947); Board of County Comm'rs v. United States, 308 U.S. 343 (1939).

s See, e.g., Board of County Comm'rs v. United States, 308 U.S. 343 (1939).

ss See United States v. National Capital Storage \& Moving Co., 265 F. Supp. 50 (D. Md. 1967). The view that "inconsistency" and "conflict" express the same standard seems to be the best approach, particularly since the two terms are used interchangeably and cases using these different terms are cited together for the same proposition. See id.

421 U.S. 454 (1975).

*7 42 U.S.C. $\$ 1981$ (1970).

421 U.S. $454,465-67$.

s. Id.

90 Conflict was used to mean direct contradiction of the purposes of the federal statute. Id.

" The Court's citation to UAW v. Hoosier Cardinal Corp., 383 U.S. 696 (1966), may imply that conflict and inconsistency are synonymous, since the references in Hoosier phrased the standard in terms of conflict. E.g., RFC v. Beaver County, 328 U.S. 204 (1946).

32 The Court adopted state law even though it explicitly recognized the significant detrimental effect of adoption on the federal cause of action. This result suggests that the inconsistency standard applied by the Court required no less interference than a conflict standard.

${ }^{3}$ E.g., United States v. Little Lake Misere Land Co., 412 U.S. 580 (1973); Sola Elec.

Co. v. Jefferson Elec. Co., 317 U.S. 173 (1942).

"See RFC v. Beaver County, 328 U.S. 204 (1946). 
rectly conflicts with a particular aspect or purpose of the federal program should not qualify for adoption. Furthermore, the purpose of the supremacy clause, resolving conflicts between federal and state law when the federal government is acting pursuant to statutory or constitutional authority, also requires precluding the adoption of state law where that law would conflict with effectuating the federal program..$^{95}$

Adoption of state law should also be precluded by a finding of inconsistency with the federal program, if "inconsistency" is merely another word for conflict. But if the term "inconsistent" refers to a degree of interference with the federal interests less than a direct negation of particular purposes of the federal program, inconsistency should not automatically prevent adoption. This result is consistent with the purpose of the adoption option. Accommodation of state and federal interests might still be achieved by adopting state law, even though that law may produce some ill effects; and the state law may provide an adequate, though not ideal, method of implementing the federal program. ${ }^{96}$ While the federal interest in avoiding interference not amounting to a conflict should not automatically preclude adoption, avoiding such interference is an important interest and therefore should be weighed with the other criteria to determine whether state law should be adopted.

This discussion of the conflict criterion suggests that a court facing the adoption issue should first consider whether applying state law would conflict with the federal program involved. If a conflict, as defined by the case law, would be created, adoption of state law should be precluded. If no such conflict is found, the court should move to a second stage of analysis where other federal interests, including the interest in avoiding interference not amounting to a conflict, should be weighed against state interests to determine the adoption issue. The bifurcated approach clarifies the analysis of the adoption issue by emphasizing the preclusive effect of the existence of a conflict and by avoiding the confusion generated by undifferentiated consideration of the three major criteria. ${ }^{97}$

${ }^{25}$ See United States v. County of Allegheny, 322 U.S. 174, 182-83 (1944).

${ }^{96}$ See Johnson v. Railway Express Agency, Inc., 421 U.S. 454 (1975). By analogy to the supremacy clause, it could also be argued that there is no constitutional reason to disqualify a state rule for adoption unless a conflict exists. Cf. United States v. County of Allegheny, 322 U.S. 174, 183 (1944).

${ }^{97}$ Considering the three factors together tends to conceal the importance accorded to the conflict criterion and to add unnecessary complexities and exceptions to analysis of the adoption issue. See, e.g., RFC v. Beaver County, 328 U.S. 204 (1946). Judicial emphasis on conflict as the major criterion and an increasingly detailed analysis of situations in which the 


\section{B. The Uniformity Criterion}

Courts dealing with the adoption issue have frequently invoked need for uniformity arguments but have seldom isolated or evaluated the various interests embodied in the general concept of uniformity. ${ }^{98}$ The weight accorded to arguments for uniformity often seems to depend more on a court's predisposition toward adopting state law than on an examination of the need for uniformity in a particular case. ${ }^{99}$ To clarify the proper significance of the uniformity arguments in adoption cases, it is necessary to catalogue the major interests underlying the uniformity criterion ${ }^{100}$ and to consider what weight should be allotted to each interest in adoption analysis.

In some opinions, the argument for uniformity seems to express no more than a desire to achieve uniformity for uniformity's sake. ${ }^{101}$ This desire does not represent a federal interest involved in implementing a federal program and therefore does not deserve weight in the balancing process. ${ }^{102}$ Furthermore, insofar as this argument for uniformity reflects an abstract desire for symmetry in the law from a federal perspective, it is inconsistent with the principles of federalism underlying the adoption option. ${ }^{103}$

Uniformity is often sought to ease the burden of federal administration. ${ }^{104}$ Large-scale federal programs are simpler and less expen-

conflict issue arises also support explicitly recognizing the impact of conflict through a twostep analysis. See, e.g., United States v. Little Lake Misere Land Co., 412 U.S. 580 (1973); UAW v. Hoosier Cardinal Corp., 383 U.S. 696 (1966).

is See Note, Rules of Decision in Nondiversity Suits, 69 YALE L.J. 1428, 1438 (1960). Recent cases exhibit more careful analysis of the uniformity criterion. See, e.g., UAW v. Hoosier Cardinal Corp., 383 U.S. 696 (1966). See also note 113 infra.

" See, e.g., Clearfield Trust Co. v. United States, 318 U.S. 363 (1943); St. Petersburg Bank \& Trust Co. v. Boutin, 445 F.2d 1028 (5th Cir. 1971) (Small Business Administration); United States v. National Bank of Commerce, 438 F.2d 809 (5th Cir. 1971); United States v. Merrick Sponsor Corp., 421 F.2d 1076 (2d Cir. 1970) (Federal Housing Administration). See generally Mishkin, supra note 3 , at 813-14.

too See generally Mishkin, supra note 3, at 813-14; Note, The Federal Common Law, 82 HaRv. L. Rev. 1512, 1529-31 (1969); Note, Rules of Decision in Nondiversity Suits, 69 Yale L.J. 1428, 1438 (1960).

101 See United States v. Standard Oil Co., 332 U.S. 301, 310 (1947); Royal Indem. Co. v. United States, 313 U.S. 289, 297-98 (1941) (Black, J., dissenting); Mishkin, supra note 3, at 813; Note, The Federal Common Law, 82 Harv. L. Rev. 1512, 1531 (1969).

${ }^{102}$ See Note, The Federal Common Law, 82 Harv. L. Rev. 1512, 1531 (1969).

${ }^{103}$ See Mishkin, supra note 3, at 813-14; text and notes at notes 35-39 supra.

101 Clearfield Trust Co. v. United States, 318 U.S. 363 (1943), can be viewed as advancing the uniformity argument in terms of ease of administration. See note 51 supra. See also United States v. Brosnan, 363 U.S. 237, 260-61 (1960) (Clark, J., dissenting); United States v. National Bank of Commerce, 438 F.2d 809 (5th Cir. 1971); Clark Inv. Co. v. United States, 364 F.2d 7 (9th Cir. 1966); Note, The Federal Common Law, 82 Harv. L. Rev. 1512, 1530 (1969); Note, Rules of Decision in Nondiversity Suits, 69 Yale L.J. 1428, 1438 (1960); cf. Bumb v. United States, 276 F.2d 729 (9th Cir. 1960). 
sive to administer if they operate identically in every state. Although ease of administration is presumably a relevant federal interest in all federal programs, the weight due this interest may vary considerably among particular programs. The purpose behind the adoption option-furthering the goals of the federal program while attempting to accommodate state and federal interests-therefore requires that the administrative problems involved in each case be specifically determined and balanced with the other federal and state interests in the adoption calculus. A generalized desire for ease of federal administration, without a determination that disuniformity would significantly undermine the functioning of the specific program involved, ${ }^{105}$ should not outweigh important state interests in the balancing process. ${ }^{106}$

It has also been argued that in some cases uniformity is necessary to avoid a conflict with the interests of a given federal program. ${ }^{107}$ This rationale for seeking uniformity involves considerations similar to those discussed in relation to the conflict criterion. If the mere diversity of state laws would create an interference amounting to a conflict, the ultimate purpose of the adoption option -implementing the federal program-would justify precluding the use of state law. However, the mere presence of disuniformity has seldom been found to result in a conflict with a federal program. ${ }^{108}$ The potential for finding such conflict is higher in certain areas of

${ }^{105}$ It is possible that the use of diverse state laws, by imposing huge administration costs, could impair operation of a federal program so seriously as to amount to a conflict with the interests of the federal program. See text and note at note 107 infra.

${ }^{106}$ See Note, Rules of Decision in Nondiversity Suits, 69 Y ALE L.J. 1428, 1447-48 (1960). Aside from Clearfield, the Supreme Court has not accorded much weight to the uniformity for administrative ease argument. It has not figured importantly in recent cases, and the Court's adoption of state law in United States v. Brosnan, 363 U.S. 237 (1960), can be viewed as a rejection of the ease of administration argument in that case.

${ }^{107}$ See De Sylva v. Ballentine, 351 U.S. 570, $583-84$ (1956) (Douglas, J., concurring). Justice Douglas urged that uniformity was necessary to further the policy of protecting dependents. Although Douglas's argument also seems to involve considerations of the content of the state laws, it is possible that he viewed a uniform rule itself as allowing more protection to dependents. In O'Brien v. Western Union Tel. Co., 113 F.2d 539 (1st Cir. 1940), uniformity was considered necessary to avoid the burden on interstate commerce which would result from using different state laws and also the burden which would result from the particular content of these laws. Clearfield Trust Co. v. United States, 318 U.S. 363 (1943), has also been viewed as considering uniformity in terms of possible impairment of federal activity. See 18 U. PitT. L. Rev. 820, 823 (1957).

${ }_{108}$ Conflict resulting from disuniformity is analytically distinguishable from other types of conflict in that it arises from the mere diversity of results under state law rather than from the particular content of the state law involved. Grounds for this special form of the uniformity argument would seem to be rare. Even De Sylva v. Ballentine, 351 U.S. 570 (1956), and O'Brien v. Western Union Tel. Co., 113 F.2d 539 (1st Cir. 1940), appear to involve a mixture of uniformity to avoid conflict and more traditional conflict arguments. 
federal legislation, such as labor relations ${ }^{109}$ and civil rights, ${ }^{110}$ which are informed by a strong policy favoring uniform standards. In such areas, lack of uniformity in itself may be viewed as detrimental. ${ }^{111}$ Even in these areas, however, adoption should not be precluded unless disuniform rules or results in connection with the particular issue involved would conflict with effective implementation of the federal program. ${ }^{112}$

A general pattern for evaluating uniformity arguments emerges from the above discussion. ${ }^{113}$ When, as in the argument for uniformity for uniformity's sake and in a generalized argument for ease of administration, the interest in uniformity is not specifically related to the operations of the federal program involved, a uniformity argument deserves little or no weight in the adoption calculus. When a lack of uniformity would actually interfere with the functioning of a specific federal program, as may be the case with a uniformity for administrative ease argument, the interest in uniformity deserves weight according to the amount of interference. When the disuniformity caused by adoption would lead to a conflict with the federal program, adopting state law should be precluded.

It is important to note that the term "uniformity" as used by the courts and as analyzed above refers to uniformity as viewed exclusively from the federal perspective. When federal law is used to obtain uniform resolution of issues substantially related to federal functions, there will often be a corresponding loss of uniformity in state regulation and in the activities of those who deal both with the Government and with private entities. ${ }^{14}$ The disruption resulting from displacing state law in an area ordinarily governed by such law

109 See, e.g., UAW v. Hoosier Cardinal Corp., 383 U.S. 696 (1966).

110 See, e.g., Marr v. Rife, 503 F.2d 735 (6th Cir. 1974).

II' See UAW v. Hoosier Cardinal Corp., 383 U.S. 696, 701-02 (1966).

112 In UAW v. Hoosier Cardinal Corp., 383 U.S. 696 (1966), the Supreme Court recognized the importance of a uniform federal labor policy. However, careful analysis led the Court to conclude that lack of uniformity on the issue in the litigation (determining the statute of limitations) would be "unlikely to frustrate" the federal policy, and therefore state law could be adopted. Id. at 702. See generally Acheson v. Falstaff Brewing Corp., 523 F.2d 1327 (9th Cir. 1975).

113 There seems to be a tendency developing in the cases to accord less importance to the uniformity criterion. Some courts have expressed hesitancy in finding a need for uniformity that will justify the utilization of federal law. See Johnson v. Railway Express Agency, Inc., 421 U.S. 454 (1975). Compare United States v. MacKenzie, 510 F.2d 39 (9th Cir. 1975), with Branden v. Driver, 441 F.2d 1171 (9th Cir. 1971), and United States v. Stadium Apts., Inc., 425 F.2d 358 (9th Cir. 1970), cert. denied, 400 U.S. 926 (1970). Other courts have demonstrated an increasing willingness to focus on and discuss the particular purposes uniformity is intended to serve in the federal activities. See UAW v. Hoosier Cardinal Corp., 383 U.S. 696 (1966).

i' See Note, The Federal Common Law, 82 Harv. L. Rev. 1512, 1531 (1969). 
may be considerable. In balancing the state and federal interests, the effects of both the new uniformity and the new disuniformity created by formulating a uniform federal law should be considered.

\section{The Local Interest Criterion}

The great majority of courts considering adoption of state law have accorded significant weight to only one state interest: a tradition of local control over the area of law in which the adoption question arises. The principal areas ${ }^{115}$ deemed to be of traditionally local concern are domestic relations ${ }^{16}$ and real property transactions. ${ }^{117}$ The emphasis given to the involvement of such areas in adoption cases ${ }^{118}$ can facilitate both the accommodation of state and federal interests and the implementation of federal programs. States have generally developed detailed laws governing relationships in these areas, and the relationships are enduring ones. To impose federal law on specific aspects of an area traditionally governed by state law would be likely to cause a significant disruption in the scheme of state regulation. ${ }^{119}$ Preventing such a large disruption of state regulation is an important state interest involved in the implementation of a federal program. This state interest is therefore justifiably accorded weight in the adoption calculus to the extent that use of a uniform federal law would actually disrupt state regulation. Furthermore, there is usually no large or detailed body of federal law developed for these areas, particularly in the field of domestic relations. Using state law in such situations provides a

"Is It has been suggested that the area of trusts and estates might also qualify as an area of primary state control. Blaney v. Florida Nat'l Bank, 357 F.2d 27, 30-31 (5th Cir. 1966). It has also been suggested that in determining whether an action involves an area of traditionally local concern, the origin of the claim being litigated should be examined. See Comment, Erie Limited: The Confines of State Law in the Federal Courts, 40 CORNELL L.Q. 561, 576-78 (1955).

116 United States v. Yazell, 382 U.S. 341 (1966); De Sylva v. Ballentine, 351 U.S. 570 (1956); see Yiatchos v. Yiatchos, 376 U.S. 306 (1964); Sitton v. United States, 413 F.2d 1386 (5th Cir. 1969), cert. denied, 397 U.S. 988 (1970).

117 United States v. Brosnan, 363 U.S. 237 (1960); RFC v. Beaver County, 328 U.S. 204 (1946); see Ideco Div. v. Chance Drilling Co., 422 F.2d 165 (5th Cir. 1970).

"I8 The weight accorded to the presence of such an area of traditionally local concern has been found to outweigh the need for uniformity, see United States v. Brosnan, 363 U.S. 237 (1960); De Sylva v. Ballentine, 351 U.S. 570 (1956), but not to overcome the preclusive effect of a finding of conflict between the state law and the interests of the federal program. See United States v. Little Lake Misere Land Co., 412 U.S. 580 (1973); RFC v. Beaver County, 328 U.S. 204 (1946).

119 The disruption of state activities and established relationships has been viewed as the major rationale for the importance accorded the presence of an area of traditionally local concern. See United States v. Yazell, 382 U.S. 341, 352-53 (1966); United States v. Brosnan, 363 U.S. 237, 241-42 (1960). 
convenient rule of decision, ${ }^{120}$ thus serving an affirmative purpose of the adoption option.

The state interest in avoiding disruptive effects on state activities outside the areas of traditionally local concern has not usually been considered in the adoption calculus. ${ }^{121}$ The policy of accommodating state and federal interests would seem to require, however, that disruptive effects on state regulation in all areas be taken into account. The major rationale used by the courts to justify the weight accorded to the existence of an area of traditionally local concern - preventing large dislocations within areas of existing state regulation-also provides a basis for considering more general disruptive effects on state activities outside the limited areas now examined. Avoiding these general disruptive effects is a state interest directly affected by the law applied in connection with the federal program. This state interest stands as the counterpart of the federal interest in uniformity. In accord with the purpose of the adoption option, this state interest should be examined in the adoption balance and weighed according to the degree of disruption presented by the facts of each case.

\section{Evaluation of the Proposed Test}

The above analysis of the three major criteria in light of the purpose of the adoption option suggests the following two-stage process for determining whether to adopt state law. ${ }^{122}$ First, a court should determine whether there is a conflict between the state law and the federal program. If a conflict is found, adoption of state law should be precluded. Second, if no conflict exists, the state and federal interests involved should be balanced. The federal interests to be considered at the second stage are the need for uniformity and

120 See De Sylva v. Ballentine, 351 U.S. 570, 580 (1956). Another explanation for the respect accorded to the presence of areas of traditionally local control is that since these areas are ones in which state law has normally governed, Congress's failure to specify the applicable law in legislation concerning such areas indicates an intent that state law should continue to govern. See United States v. Brosnan, 363 U.S. 237, $241-42$ (1960); United States v. Standard Oil Co., 332 U.S. 301, 308-09 (1947).

121 Some recent cases do suggest that state interests other than those connected with traditionally local control be considered in determining whether to adopt state law. See United States v. Little Lake Misere Land Co., 412 U.S. 580, 599-603 (1973); United States v. MacKenzie, 510 F.2d 39, 41-42 (9th Cir. 1975).

122 The proposed test is aimed at clarifying and modifying the existing mechanism for determining whether to adopt state law. The bifurcated procedure clarifies the determinative role of the conflict criterion, a role often apparent in the cases. See text and notes at notes 73,93 supra. The test also modifies the weight and elements of the other two criteria. A few recent cases have suggested modifications similar to those used in the proposed test. See notes 113,121 supra. 
the avoidance of interference, not amounting to a conflict, with a federal program. The relevant state interests are preserving the structure of state regulation in areas of traditionally local concern and avoiding disruptive effects on the operation of state law in other areas.

This proposed test is an improvement over traditional formulations in that it explicitly recognizes the importance of the conflict criterion and defines its proper scope, eliminates the overemphasis on a generalized need for uniformity argument, and recognizes a broader range of valid state concerns in the balancing process. The content of the proposed standard-the factors chosen for analysis and the weight accorded them-and the procedure suggestedbifurcation and balancing-are justified in terms of the purpose of the adoption option and are designed to yield results consonant with that purpose.

Objections might be raised to the proposed test, and particularly to its balancing phase, on the grounds that it fails to prescribe a sufficiently specific mechanism for decision and that it allows subjective determination of the adoption question. ${ }^{123}$ An examination of the proposed test indicates, however, that it does provide some checks on the potential for subjective determination. While elements of subjectivity are not completely eliminated, some degree of indefiniteness appears inevitable if state and federal interests are to be accommodated. ${ }^{124}$

The first stage of the proposed test, ascertaining whether there is a conflict between a state law and a federal program, does not pose great problems of subjectivity or indefiniteness. Courts have evolved procedures for determining the purposes of federal pro-

123 These objections are similar to those raised against Brainerd Currie's interest analysis approach to resolving conflict of laws issues. For discussion of criticisms of the Currie method, see Currie, The Verdict of the Quiescent Years: Mr. Hill and the Confict of Laws, $28 \mathrm{U}$. CHI. L. REv. 258 (1961); Hill, Governmental Interest and the Confict of Laws-A Reply to Professor Currie, 27 U. ChI. L. REv. 463 (1960); Kozyris, No-Fault Automobile Insurance and the Confict of Laws-Cutting the Gordian Knot Home-Style, 1972 DukE L.J. 331, 348-51; Reese, Recent Developments in Torts Choice-of-Law Thinking in the United States, 8 Colum. J. TransnaT't. L. 181 (1969).

124 Compare the proposal of a similar type of standard to analyze preemption questions and the rationale developed to justify the utilization of that standard in Hirsch, Toward a New View of Federal Preemption, 1972 U. ILL. L.F. 515. That standard also specified factors to be considered in order to avoid problems of subjective evaluation, but, largely due to the complex interrelationship between state and federal law in the preemption area, did not provide precise weights to be attributed to particular factors. Because adoption and preemption questions share the problem of discerning the relationship between federal and state law in individual cases, preemption concerns and solutions are relevant in considering objections to the proposed standard. 
grams, and they assess possible conflicts between state law and the interests of federal programs in other contexts requiring choice of law determinations. ${ }^{125}$ In addition, the conflict concept has been fairly well developed by the courts in the adoption context, and its application can be checked against the purpose of the adoption option.

The proposed test also provides protections against excessive subjectivity in the balancing stage. First, the test identifies the components of state and federal interests that must be considered in every case: avoiding disruption of existing state regulation, achieving uniformity, and avoiding interference with the operation of a federal program. Second, the components that are balanced are fairly objective, as opposed to evaluative. The state interest considered at this stage is the impact that disregarding state law would have on existing state regulation. This impact is to be determined by focusing on the effects on activities conducted under the state law; the court is not to evaluate the wisdom of the general policies underlying the state's position. ${ }^{126}$ The proposed test provides a similarly nonsubjective approach for analyzing federal interests: in considering uniformity and interference arguments, courts would be limited to determining the actual impact on the specific federal program, as opposed to evaluating the wisdom of the program. Furthermore, the proposed test indicates general guidelines for assessing the weights to be assigned the federal and state interests involved in the balancing stage.

These features of the proposed test do not eliminate the problem of indefiniteness entirely, but some lack of precision in advance of judgment seems inherent in adoption questions. ${ }^{127}$ Accommodating the state and federal interests in connection with the operation

${ }^{125}$ One basis for preemption decisions, for example, is a finding of conflict between the state and the federal laws; the meaning of conflict in this context is similar to its meaning in the adoption area. See Note, The Preemption Doctrine: Shifting Perspectives on Federalism and the Burger Court, 75 CoLuM. L. REv. 623 (1975). See generally Hirsch, supra note 124.

${ }^{128}$ Compare this standard with Currie's interest analysis approach, see note 123 supra, which seems to require a determination of the policies and interests of the state in applying its own law. See Reese, supra note 123, at 187.

${ }^{127}$ See the detailed discussions of the complex interrelationships involved in this area of federal-state relations in Hart, supra note 20, and Mishkin, supra note 3. Compare with the proposed test the approach suggested by Hirsch to the similar interrelationships involved in preemption questions. Hirsch, supra note 124. In United States v. Little Lake Misere Land Co., 412 U.S. 580 (1973), the Supreme Court faced the problem of this inherent imprecision and indicated a willingness to engage in the analysis and examination of state and federal interests necessary to determine the adoption issue with regard to the particular circumstances of the case. 
of a particular federal program requires a consideration of the relationship between the specific state law and federal program involved. Since the precise degrees of impact that the state law would have on the federal program and that a uniform federal law would have on state regulation depend on the particular characteristics of the laws and the program in question, no precise quantification of the weight to be accorded state and federal interests can be stated in advance. The proposed test does provide a framework within which this determination can be made, but courts must make the determination of the specific weight to be accorded these interests on the basis of the particular circumstances of each case.

Alternative tests which attempt to provide a more precise standard fail to fulfill the purposes behind the adoption option. One possible method for determining the choice of law issue would be to provide either that a uniform federal law would always apply or that state law would always be adopted in adoption situations. While this approach would eliminate imprecision, it would not in any way accommodate state and federal interests. Such an approach would be inconsistent with the determination which has been made that neither the federal nor the state interests are sufficient to mandate the exclusive application of either state or federal law in all adoption situations. ${ }^{128}$ Following this approach would sacrifice the flexibility of adoption techniques for cases in which state law is a useful and convenient tool for implementing a federal program and for those in which uniform federal law is more appropriate. ${ }^{129}$

A second approach would be to adopt state law unless the state law would conflict with the interests of the federal program. While this approach avoids the necessity of identifying the state interests and balancing them against the federal interests, it cannot thoroughly accommodate state and federal interests because it fails to consider interference with federal interests that, though significant, does not amount to a conflict.

A third approach would be to adopt state law unless a conflict is present or unless the federal interests are infringed to a certain degree amounting to less than a conflict. ${ }^{130}$ This test is more respon-

${ }^{128}$ See p. 829 supra.

129 Additional support for rejecting the alternative of utilizing federal law in all adoption situations is provided by courts' hesitation to develop federal law judicially unless a fairly urgent need for this development is shown. See Wallis v. Pan Am. Petroleum Corp., 384 U.S. 63 (1966); Wheeldin v. Wheeler, 373 U.S. 647 (1963); United States v. Bldg. \& Constr. Trades Council, 271 F. Supp. 447 (E.D. Mo. 1966).

${ }^{130}$ A similar approach was proposed in 49 N.C.L. REv. 358, 365 (1971), suggesting that there should be a presumption in favor of adopting state law which could be rebutted by a showing of sufficient federal interest in the utilization of federal law. 
sive to the federal interests involved and would avoid the necessity of determining the weight of state interests and balancing this weight against that of the federal interests. Nevertheless, this test involves some difficulties. While automatically precluding adoption when the interference with federal interests amounts to a conflict is justified in terms of the purpose of the adoption option, that purpose affords no basis for determining what degree of impairment short of a conflict should automatically preclude adopting state law. Wherever the line representing the sufficient degree of impairment is drawn, the third test will yield some results which are incorrect in terms of the purpose of the adoption option. By eliminating the balancing stage, the test would require the rejection of state law in all situations in which federal interests reached a certain magnitude, even when state interests would be greater on balance. ${ }^{131}$ On the other hand, state law would be adopted even when federal interests, though not reaching the magnitude required by the test, outweighed the state interests. These incorrect results might more heavily favor federal or state interests depending on whether the line representing the necessary impairment of federal interests is placed at a low or high level.

A related problem with the third approach is the difficulty of developing a discrete concept to express the degree of interference less than a conflict which should preclude adoption. The standard would presumably have to be formed in such loose terms as "significant" or "substantial" impact. Since the impact on federal interests would have to be evaluated in terms of such nonspecific concepts, the third test does not appear to offer any significant gains in clarity over the proposed test.

The imprecision of the standard for determining the level of interference necessary to preclude adoption and the absence of any assessment of the state interests involved under this alternative test may create a systemic bias favoring the use of uniform federal law. If some degree of harm to federal interests exists, courts may well tend to find this harm sufficient to mandate a uniform federal law, preferring to protect known federal interests rather than the unknown state interests.

เ3 The possibility of incorrect results in favor of federal law is most grave in situations in which the state law involved is in an area of traditionally local concern. See United States v. Yazell, 382 U.S. 341 (1966); United States v. Brosnan, 363 U.S. 237 (1960); RFC v. Beaver County, 328 U.S. 204 (1946). 
On balance, the test this comment proposes seems the most appropriate one for determining whether to adopt state law. The alternative tests attempt to provide a more precise rule by eliminating the balancing of federal and state interests but would be likely to yield results inconsistent with the purpose of accommodating those interests. The third test, although possibly more attuned than the first two to the purpose of the adoption option, would still yield results inconsistent with that purpose in some situations, and the potential for incorrect results is not justified by any real gain in precision. Consideration of these alternative tests supports the conclusion that the proposed test's failure to specify more precisely the weights to be accorded the interests involved in particular cases is inescapable if the purpose of the adoption option is to be systematically pursued. Of course, as cases are decided in light of the purpose of the adoption option, the weights to be accorded particular federal and state interests will become more precise. ${ }^{132}$

\section{Application of the Proposed Test to the Farmers Home Administration Cases}

The circuit courts are presently in conflict over whether state law should be adopted in actions by the Government against auctioneers for conversion arising out of the sale of cattle on which the Government had chattel mortgages. The major issue in this series of cases is whether lack of knowledge of the mortgages is a defense. ${ }^{133}$

132 For an attempt to utilize previous determinations of relative weight in the adoption area, see United States v. MacKenzie, 510 F.2d 39 (9th Cir. 1975). Cf. Hirsch, supra note 124 , at 558 .

${ }^{133}$ See cases cited notes 7, 8 supra. One of these cases, United States v. Hext, 444 F.2d 804 (5th Cir. 1971), involved the sale of mortgaged cotton, rather than mortgaged cattle. Although the holding of the case as to the liability of those trading in property mortgaged to the Government depended on the particular facts of the case, the court's decision to use a uniform federal law to resolve the liability issue was based on factors similar to those considered in the cattle auctioneer cases. In addition, the Hext court in dicta affirmed the result reached by the courts using uniform federal law in the cattle auctioneer cases. $444 \mathrm{~F} .2 \mathrm{~d}$ at 810-11. Perhaps because the adoption issue in Hext appears so closely analogous, cases dealing with cattle auctioneers have often cited Hext without distinguishing it on the grounds of the particular fact situation involved. The major cases are generally discussed in Note, Auctioneers' Liability for Conversion Under the Packers and Stockyards Act, 67 YALE L.J. 504 (1958); 5 B.C. Ind. \& Com. L. Rev. 790 (1964); 45 Calif. L. Rev. 776 (1957); 43 Notre Dame Law. 132 (1967); 105 U. PA. L. Rev. 266 (1956). It has been asserted that this conflict among the circuits might become academic in the future since one case, United States v. Hext, 444 F.2d 804 (5th Cir. 1971), has suggested that a federal rule be patterned after the Uniform Commercial Code. United States v. E.W. Savage \& Son, Inc., 343 F. Supp. 123, 125 n.1 (D.S.D. 1972), aff'd, 475 F.2d 305 (8th Cir. 1973); see United States v. McClesky Mills, Inc., $409 \mathrm{~F} .2 \mathrm{~d} 1216$ (5th Cir. 1969). However, Hext is the only major decision relying on the U.C.C. to formulate the federal rule in this area, and the state U.C.C. provisions relevant to 
Applying the test proposed in this comment to the FmHA cases resolves this conflict and demonstrates the operation of the test.

\section{A. The Farmers Home Administration Program}

An analysis of the legislative history and statutory scheme of the program ${ }^{134}$ reveals that the prerequisites for adoption analysis are present and provides a framework for evaluating the federal and state interests involved. The primary purpose of the FmHA loan program is to enable farmers who cannot qualify for commercial or other government credit to acquire and maintain farm ownership. ${ }^{135}$ The program emphasizes aiding farmers rather than conducting a profitable business venture; ${ }^{136}$ lending to farmers regardless of their creditworthiness was justified as a form of social lending with national benefits. ${ }^{137}$

Congress never considered what law might govern the liability of auctioneers or others acting as conduits for property mortgaged to the Government under the FmHA programs. Nor did Congress emphasize general procedures for collecting loans in the event of default. ${ }^{138}$ Instead, Congress looked primarily to the selection proce-

auctioneer liability appear to vary; the question would still require resolution in those states where the U.C.C. is contrary to the federal law in Hext. See United States v. Big Z Warehouse, 311 F. Supp. 283 (S.D. Ga. 1970). Finally, there actually has been a conflict in this area without significant reference to the U.C.C. This conflict among the circuits regarding the application of the standard for determining whether to adopt state law and the positions of the various circuits, particularly the Eighth Circuit, are also evidenced in connection with other areas of FmHA administration-waiver of liens and consent to sale: see, e.g., United States v. Central Livestock Ass'n, 349 F. Supp. 1033 (D.N.D. 1972); United States v. Loken, 291 F. Supp. 432 (D.S.D. 1968); United States v. Hansen, 203 F. Supp. 326 (S.D. Iowa 1962), aff'd, 311 F.2d 477 (8th Cir. 1963); and priority of liens: see, e.g., United States v. GregoryBeaumont Equip. Co., 243 F.2d 591 (8th Cir. 1957); United States v. Squires, 378 F. Supp. 798 (S.D. Iowa 1974); Fred W. Beal, Inc. v. Allen, 287 F. Supp. 126 (D. Me. 1968).

134 The most recent legislation on the FmHA is the Consolidated Farmers Home Administration Act of 1961. Agriculture Act of 1961, tit. III, 75 Stat. 307 (codified in scattered sections of 7 U.S.C.).

135 See, e.g., Hearings on S. 1800 Before a Subcomm. of the Senate Comm. on Agriculture and Forestry, 74th Cong., Ist Sess. 11, 23 (1935). No hearings were held on the Senate bill introduced in the session in which the Bankhead-Jones Farm Tenant Act (the initial legislation in the area of FmHA loans) was passed. The Act followed closely the provisions of $\mathrm{S}$. 1800 , on which hearings were held.

${ }^{136}$ See id. at 23, 33, 49 (1935); 81 Cong. Rec. 6469 (1937) (remarks of Rep. Biermann).

${ }_{137}$ See Hearings on H.R. 4384 Before the House Comm. on Agriculture, 78th Cong., $2 \mathrm{~d}$ Sess. 43-44 (1944) (statement of Mr. Westbrook). H.R. 4384 was a predecessor bill to that intraduced in the House during the session that the Farmers Home Administration Act of 1946 was adopted. No hearings were held on the latter bill; instead the hearings on H.R. 4384 were relied on in the congressional debates. See 92 Cong. REc. 3362 (1946) (remarks of Rep. Cooley).

${ }^{13 \times}$ See, e.g., Hearings on S. 1800 Before a Subcomm. of the Senate Comm. on Agriculture 
dure and to continuing supervision of loan recipients to protect the Government's security interests. ${ }^{139}$ Congress did not stress any need for uniform procedures or results under the program; ${ }^{140}$ rather, the need for decentralized administration and local cooperative efforts was emphasized. ${ }^{41}$ The lack of congressional attention to the problem of auctioneers' liability and the lack of emphasis on uniformity, coupled with the fact that the issue arises from the operation of a federal program, ${ }^{142}$ opens the possibility of adopting state law. ${ }^{143}$

\section{B. The Conflict Criterion}

The majority of state laws involved in those FmHA cases which analyzed the content of the laws provided the auctioneer with a defense to an action for the conversion of mortgaged chattels if the auctioneer did not know of the mortgage; the uniform federal law, either preexisting or formulated in the cases, precluded such a defense. ${ }^{144}$ Application of the conflict criterion requires a determination of whether allowing a defense based on lack of knowledge of the mortgage would nullify aspects of the FmHA program.

No court expressly concluded that a direct conflict was present. Indeed, two of the courts which adopted state law argued that using familiar and developed state laws would facilitate the business transactions involved with the FmHA programs, thereby helping both the farming community at large and the low-income farmers for whose benefit the program was designed. ${ }^{145}$ Nevertheless, some

and Forestry, 74th Cong., 1st Sess. 23, 33 (1935); 81 CoNG. REc. 6469, 6679 (1937) (remarks of Rep. Biermann and Sen. Connally).

139 See, e.g., 81 CoNG. REc. 6454 (1937) (remarks of Rep. Wadsworth).

iso See, e.g., id. at 6459, 6478 (1937) (remarks of Rep. Hope and Rep. Cooley).

is See, e.g., id. at 6459 (1937) (remarks of Rep. Hope).

142 See United States v. Sommerville, 324 F.2d 712, 716 (3d. Cir. 1963).

143 The FmHA regulations, 7 C.F.R. $\$ \S 1800.1-1980.495$ (1976), also do not address the question of third party liability for conversion. In the event of sale of the chattel, the regulations emphasize collection from the borrower before proceeding against a third party. See, e.g., id. $\S 1871.22$ (1976). The regulations considering possible liability of third parties concern third party purchasers, not auctioneers. See, e.g., id. $\$ 1871.22$ (1976). Compare these FmHA regulations, with 7 C.F.R. $\S \S 1800.41-.42$ (1976), providing that federal law governs a wife's liability, presumably in response to United States v. Yazell, 382 U.S. 341 (1966).

is United States v. Chappell Livestock Auction, Inc., 523 F.2d 840 (8th Cir. 1975); United States v. Carson, 372 F.2d 429 (6th Cir. 1967); United States v. Kramel, 234 F.2d 577 (8th Cir. 1956). In United States v. Sommerville, 324 F.2d 712 (3d Cir. 1963), cert. denied, 376 U.S. 909 (1964), the content of the state law was not specified because the courts focused on the need for uniformity. In United States v. Matthews, 244 F.2d 626 (9th Cir. 1957), the court did not discuss the content of state law because both parties agreed that federal law should govern. In United States v. Union Livestock Sales Co., 298 F.2d 755 (4th Cir. 1962), both state and federal law imposed liability without knowledge.

is See United States v. Chappell Livestock Auction, Inc., 523 F.2d 840, 841 (8th Cir. 1975); United States v. Union Livestock Co., 298 F.2d 755, 759 (4th Cir. 1962). 
of the courts which used a uniform federal law focused on certain aspects of the state laws in a way which can be viewed as raising conflicts arguments. ${ }^{146}$ Asserting that one purpose of the program was protection of the Government's security in the loans, ${ }^{147}$ these courts argued that holding an auctioneer strictly liable helped safeguard the Government's interests by providing an additional remedy to augment the security of the loans. ${ }^{148}$ The courts also suggested that loans would not be as readily available if the only remedy for conversion were against the borrower. ${ }^{149}$

A persuasive argument can be made that adopting state laws allowing lack of knowledge as a defense would not conflict with the purposes of the FmHA program. Conflict, as defined by the courts, implies a nullification of aspects of the federal program involved, a contradiction of the purposes of the program. ${ }^{150}$ The two major effects of using the state laws in question are that the auctioneer who has no knowledge of an outstanding mortgage is relieved of liability and that the Government, unless it can collect from the borrower, assumes the loss from the unauthorized sale of mortgaged cattle. Neither of these results impairs the operation of the FmHA program to a degree that creates a conflict.

Using state law that allows auctioneers who have no knowledge of outstanding mortgages to avoid liability has no detrimental impact on the purpose of the FmHA program, aiding high-risk farmers. Rather, the major effect on FmHA loan recipients would be to preserve for their sales the same legal consequences which attend the transactions of other farmers within the state. When the state law provides a defense of lack of knowledge in connection with other mortgages, to preclude this defense for FmHA mortgages alone would place FmHA farmers in these states at a comparative disad-

${ }^{116}$ The arguments on the conflict, uniformity, and local interest criteria in the text have been collected from various cases and organized to present a more coherent and complete position.

Is7 See United States v. Carson, 372 F.2d 429, 433 (6th Cir. 1967). Given the frequent characterization of the FmHA program as a measure to aid farmers, attributing such a commercial purpose to the program seems incorrect. See text and notes at notes 135-37 supra. See, e.g., Hearings on S. 1800 Before a Subcomm. of the Senate Comm. on Agriculture and Forestry, 74th Cong., 1st Sess. 23, 33 (1935) (statements of Mr. Gray and Mr. Rankin); 81 CoNG. REc. 6469 (1937) (remarks of Rep. Biermann).

14S See United States v. Carson, 372 F.2d 429, 433-35 (6th Cir. 1967); United States v. Sommerville, 324 F.2d 712, 717 (3d Cir. 1963), cert. denied, 376 U.S. 909 (1964).

1" United States v. Sommerville, 324 F.2d 712, 717 (3d Cir. 1963), cert. denied, 376 U.S. 909 (1964).

150 See text and notes at notes 73-78 supra. 
vantage to other farmers, ${ }^{151}$ thereby harming those whom the program is designed to aid. ${ }^{152}$

Nor would imposing the losses incurred through unauthorized sales of FmHA mortgaged property on the Government conflict with the purpose or functioning of the FmHA program. ${ }^{153}$ Placing such costs on the Government does not endanger the existence of the FmHA loan programs. Congress has expressed satisfaction with the record of repayment of $\mathrm{FmHA}$ loans, ${ }^{154}$ indicating that the amount

${ }^{15 t}$ This discussion is not meant to suggest that denying a defense for the auctioneer will always have a detrimental effect on FmHA farmers. Denying such a defense in regard to FmHA mortgages in a state which generally denies the defense in actions for conversion of mortgaged properties would not disadvantage FmHA farmers. Rather, denying the defense in such states would again preserve for FmHA farmers the same legal ramifications accorded the transactions of other farmers.

${ }_{152}$ An auctioneer in a state which generally allows lack of knowledge that the goods he sells are mortgaged as a defense has two options if no such defense is allowed in connection with FmHA mortgages: he could attempt to protect himself by learning of the existence of the government mortgage, or he could assume liability without knowledge and insure against it. The first alternative is problematic. An auctioneer usually does not know what cattle are going to be auctioned until the day of the sale. See United States v. Sommerville, $211 \mathrm{~F}$. Supp. 843 (W.D. Pa. 1962), aff'd, 324 F.2d 712 (3d Cir. 1963), cert. denied, 376 U.S. 909 (1964). He would therefore probably have to obtain information about all the farmers who had FmHA chattel mortgages on their cattle. While lists of borrowers are available, the lists are required to carry warnings of inaccuracy or incompleteness. 7 C.F.R. $§ 1871.6$ (1976). After obtaining information concerning those farmers with FmHA mortgages, the auctioneer might decide not to handle any of the cattle of farmers who had FmHA mortgages because of uncertainty concerning which cattle of a particular farmer are mortgaged. See, e.g., Cassidy Comm'n Co. v. United States, 387 F.2d 875 (10th Cir. 1967). Alternatively, he might charge more to farmers with FmHA mortgages because of doubt concerning the mortgaged status of the cattle. On the other hand, if the auctioneer determines to assume the risk of possible liability and to insure against it, he would probably increase his commission. If he increased his commission for FmHA farmers only, these farmers would again be put at a disadvantage compared to other farmers by the extra expense. The effect of any of these steps is to disadvantage the FmHA farmers by imposing obstacles to their marketing of cattle which are not imposed on other farmers in the state, since sales for these other farmers would not expose the auctioneer to liability.

${ }_{153}$ See generally Ault v. Harris, 317 F. Supp. 373 (D. Alas. 1968), aff'd mem., 432 F.2d 441 (9th Cir. 1970) (arguing that the protection of the federal treasury should not be controlling when the Government is engaged in local money-lending activities). Arguments for protecting the federal fisc by changing the elements of a cause of action related to the administration of a program can and should be dealt with by Congress. See United States v. Standard Oil Co., 332 U.S. 301 (1947). In fact, Congress has attempted to alter the distribution of costs under another agricultural program through changing the elements of a cause of action related to the administration of this program. In the Agricultural Act of 1961, Title III of which was the Consolidated Farmers Home Administration Act of 1961, Congress eliminated the requirement of "willfulness" from the cause of action in civil proceedings for exceeding quotas under the Agricultural Marketing Agreement Act of 1937; the stated purpose of this elimination was to increase the ease and effectiveness of enforcement of the provisions of the Act. See H.R. ReP. No. 839, 87th Cong., 1st Sess. 30 (1961).

is See Hearings on H.R. 6400 Before the House Comm. on Agriculture, 87th Cong., 1st Sess. 615, 644 (1961); 107 Cong. Rec. 13752 (1961) (remarks of Rep. Matthews). The charge- 
lost through all defaults has not had a large impact on the continuing viability of the program. ${ }^{155}$ Furthermore, by adopting this social lending program, the Government was arguably willing to assume the burden of some losses in this high credit risk area.

Once it has been determined that there is no conflict between the state law and the federal program, the proposed test requires a balancing of state and federal interests. ${ }^{156}$

\section{The Uniformity Criterion}

While numerous arguments concerning uniformity ${ }^{157}$ were discussed in the cases on this issue, uniformity was invoked more as a talisman than as an analytical tool. The courts which have adopted state law have contended that there is no need for uniformity in connection with these loan transactions, ${ }^{158}$ bolstering this argument

off and judgment rates on FmHA loans were also considered low. See Hearings on H.R. 6400 Before the House Comm. on Agriculture, 87th Cong., 1st Sess. 621 (1961). And it was felt that the rate of refinancing under the programs was good. (Refinancing under another loan program is required when a farmer is able to assume loans with higher interest rates.) See id. at 634 . The hearings on H.R. 6400 were the House hearings on the Agricultural Act of 1961, Title III of which was the Consolidated Farmers Home Administration Act of 1961.

${ }^{135}$ After expressing satisfaction with the level of repayment, Congress loosened some of the restrictions on FmHA loans in the Consolidated Farmers Home Administration Act of 1961, the most recent major legislation governing the FmHA. See Hearings on H.R. 6400 Before the House Comm. on Agriculture, 87th Cong., 1st Sess. 657 (1961). For example, both direct and insured loans were authorized to be made up to 100 percent of the value of real estate security. See id. at 616 (1961). In addition the limits on the amount of loans available were raised. See 107 Cong. REc. 13477 (1961) (remarks of Rep. Cooley).

158 Interferences with the federal program not amounting to a conflict are not considered in the balancing stage in connection with these FmHA cases. As implied in the consideration of the conflict criterion, adoption of state law providing a defense to liability in states which generally provide such a defense does not seem to have a detrimental impact on the purpose or functioning of the FmHA programs, but rather seems to be in consonance with them. Arguments based on interferences not amounting to a conflict should therefore carry little weight. Since the arguments on interference would be essentially identical to those already discussed in regard to conflict, they are not treated separately in the text.

${ }^{157}$ Two introductory points concerning uniformity in the FmHA context should be noted. First, refusal to adopt state law may not necessarily lead to uniformity in this context because the courts have drawn on various authorities as the source of their "uniform" federal law. See, e.g., United States v. Hext, 444 F.2d 804 (5th Cir. 1971); United States v. Carson, 372 F.2d 429 (6th Cir. 1967); Mishkin, supra note 3, at 813. Second, the FmHA has the power to change its regulations so as to require a uniform federal law. Cf. 7 C.F.R. $\$ \$ 1800.41-.42$ (1976) (requiring that the FmHA liability of wives be governed by federal law). See also note 143 supra. The fact that the FmHA has not promulgated such regulations in connection with auctioneer liability seems to imply that it is unconcerned with the present disuniform state of the law.

15* See United States v. Chappell Livestock Auction, Inc., 523 F.2d 840 (8th Cir. 1975); United States v. Kramel, 234 F.2d 577 (8th Cir. 1956). This argument basically seems to be dealing with uniformity of administration. See, e.g., United States v. Kramel, 234 F.2d 577, 580-81 (8th Cir. 1956). 
by noting the absence of any congressional indication that uniformity was necessary. ${ }^{159}$ In contrast, the courts which have refused to adopt state law have contended that uniformity is necessary, arguing that the diversity of legal effects resulting from adopting state law would undermine the administration of the program because the program itself and the terms of the loans would have to be framed with reference to the particular law of each state. ${ }^{160}$ These courts have also taken the position that state law should not be used without a clear congressional intent to do so. ${ }^{161}$ Finally, these courts have suggested that uniformity is necessary to prevent uncertainty, particularly the uncertainty which could result from changes in state law. ${ }^{162}$

The arguments for and against uniformity focus primarily on uniformity for purposes of easing federal administration. ${ }^{163}$ The purpose underlying the adoption choice does not justify giving great

159 See United States v. Chappell Livestock Auction, Inc., 523 F.2d 840, 841 (8th Cir. 1975); United States v. Kramel, 234 F.2d 577, 580-81 (8th Cir, 1956).

${ }^{160}$ See United States v. Sommerville, 324 F.2d 712 (3d Cir. 1963), cert. denied, 376 U.S. 909 (1964). This argument was specifically recognized as dealing with uniformity for purposes of administrative ease. Id. at 716.

${ }_{181}$ See United States v. Sommerville, 324 F.2d 712, 717 (3d Cir. 1963), cert. denied, 376 U.S. 909 (1964). In both lines of cases the arguments concerning congressional intent on the subject of uniformity seem irrelevant at this stage in evaluating the need for uniformity; if Congress had indicated that uniformity was necessary, the issue of whether to adopt state law would not have arisen. These arguments are best viewed as revealing a predisposition in favor either of using federal law or of adopting state law, or as indicating the weight which a court feels should be given the need for uniformity in balancing it against the specific local interests involved.

${ }^{162}$ See United States v. Hext, 444 F.2d 804 (5th Cir. 1971). Again this argument suggests an emphasis on administrative ease, since it is not argued that this uncertainty would conflict with the interests of the federal program, but only that it would render the administration of the program somewhat more difficult.

${ }^{163}$ See United States v. Sommerville, 324 F.2d 712, 716 (3d Cir. 1963), cert. denied, 376 U.S. 909 (1964); United States v. Kramel, 234 F.2d 577, 580-81 (8th Cir. 1956). See also notes 158-62 supra. The argument made in United States v. Sommerville, $324 \mathrm{~F} .2 \mathrm{~d} 712$ (3d Cir. 1963), cert. denied, 376 U.S. 909 (1964), can be viewed as attempting to establish that the "uncertainty" created by adopting state law would actually impair the FmHA loan program. Given the operation and purposes of the FmHA program, however, it is unlikely that adopting state law would either impose a great administrative burden or interfere significantly with the implementation of the program. "Uncertainty" as to the outcome of litigation by the Government in the individual states could easily be overcome by examining the laws of the particular states involved. Whether or not lack of knowledge is a defense to an action in a particular state is a relatively clear-cut issue, and since the administration of the program is decentralized, the FmHA would have frequent contact with state law. If, however, "uncertainty" refers to the possibility of the Government's being unable to collect a judgment from an auctioneer in all states, suggesting that an inability to collect would harm the operation of the FmHA program, see United States v. Sommerville, 324 F.2d 712, 714-15 (3d Cir. 1963), cert. denied, 376 U.S. 909 (1964), the argument blends into the conflict/interference argument, which has been discredited above. See text and notes at notes 153-56 supra. 
weight to ease of administration arguments unless disuniformity would have a significant detrimental impact on the administration of the specific program involved..${ }^{164}$ Disuniformity is unlikely to have a serious detrimental impact on the administration of the FmHA loan program since much of the program is decentralized and administered through local committees. ${ }^{165}$

\section{The Local Interest Criterion}

In analyzing this factor, the courts have focused on whether the area of law in question is one of traditionally local concern. Courts which have adopted state law have argued that state tort law affecting title to personal property is an area of traditionally local concern, ${ }^{166}$ while those which have utilized uniform federal law have argued that this area of law does not fall within the major categories accorded such status-real property transactions and domestic relations. ${ }^{167}$

Concededly, this area of law does not fall within these two categories. However, in United States $v$. Standard Oil Co. ${ }^{168}$ the Supreme Court suggested that some aspects of tort law may involve questions of peculiarly local concern. ${ }^{169}$ The major reason for according great weight to areas of particularly local concern, the dislocation that would result if an integrated area of state law were partially subjected to federal control, ${ }^{170}$ is present in the FmHA cases. Even if this dislocation is not considered severe enough to warrant the conclusion that the area of state law involved is one of traditionally local concern, it is sufficient to support a strong state interest in favor of adopting state law. ${ }^{171}$

ist See text and notes at notes 104-06 supra. Recent cases suggest that uniformity for administrative ease is being deemphasized as a ground for utilizing a uniform federal law. See United States v. O'Connell, 496 F.2d 1329, 1332 (2d Cir. 1974); cf. Bumb v. United States, 276 F.2d 729, 738 (9th Cir. 1960). See also note 113 supra.

${ }^{165}$ See text and note at note 141 supra; cf. United States v. Yazell, 382 U.S. 341 (1966); RFC v. Beaver County, 328 U.S. 204 (1946); Ewing v. Small Business Administration, 359 F. Supp. 16 (E.D. La. 1973).

Ist See United States v. Chappell Livestock Auction, Inc., 523 F.2d 840 (8th Cir. 1975); United States v. Kramel, 234 F.2d 577, 581 (8th Cir. 1956). These cases argued that in areas of local concern, there must be substantial reasons to override state law, such as a clear congressional intent to do so.

${ }^{167}$ See United States v. Carson, 372 F.2d 429, 434 (6th Cir. 1967). This narrow approach to areas of traditionally local concern can be viewed as indicating that little weight is being given to state interests in deciding the adoption question.

w* 332 U.S. 301 (1947).

i'" Id. at 310-11.

17 See United States v. Brosnan, 363 U.S. 237, 241-42 (1960); text and note at note 119 supra.

${ }^{17}$ See United States v. Little Lake Misere Land Co., 412 U.S. 580, 599 (1973); text at 
State laws providing a lack of knowledge defense to liability for cattle auctioneers further the quick flow of livestock in commerce. ${ }^{172}$ Carving out a segment of the auctioning process in which federal law would apply would create disuniformity which would impair expeditious commerce in cattle. ${ }^{173}$ This impairment could be significant since a large percentage of cattle marketing, particularly in the states in which these actions have arisen, is conducted through such private auctions. ${ }^{174}$ The local interest criterion therefore weighs heavily in favor of adopting state law.

\section{E. Resolution of the Adoption Question}

The proposed test dictates that state law should be adopted in the FmHA cases. There is no conflict between state laws providing a defense of lack of knowledge to an auctioneer and the interests of the FmHA program. In the balancing stage of the analysis, the federal interest in uniformity is fairly weak, while the dislocation of state activities resulting from the utilization of a uniform federal law would be serious. The state interests outweigh the federal interests, and therefore state law should be adopted.

\section{ConCLusion}

This comment has attempted to develop a test for determining whether a court should adopt state law as the content of a federal

note 121 supra.

${ }_{172}$ See United States v. Chappell Livestock Auction, Inc., 523 F.2d 840, 842 n.2 (8th Cir. 1975).

${ }^{173}$ Id.; cf. O'Brien v. Western Union Tel. Co., 113 F.2d 539 (1st Cir. 1940). Auctioneers' attempts to protect against liability imposed by a federal law would probably aggravate the detrimental effects a special federal law would have on the flow of commerce. See note $\mathbf{1 5 2}$ supra.

17 See H. DeGraff, Begf: Production and Distribution 154 (1960). For a description of the activities involved with a private auction, see United States v. Sommerville, $211 \mathrm{~F}$. Supp. 843 (W.D. Pa. 1962), aff'd, 324 F.2d 712 (3d Cir. 1963), cert. denied, 376 U.S. 909 (1964). The fact situation in the FmHA cases suggests an additional difficulty caused by using a uniform federal law different from the general state law to govern an issue in an adoption context. In these cases the Government is attempting to recover from third parties with whom it had no original dealings. These third parties may not have expected to deal with the Government or to have their activities judged according to federal standards. In the FmHA cases, it might be possible for an auctioneer to ascertain whether he would potentially be dealing with the Government through a search of the record of chattel mortgages or from lists obtained from the FmHA, see note 152 supra (concerning the possible inaccuracy of these lists), but this solution begs the question, since the issue in these cases is whether this burden should be placed on the auctioneer. Furthermore, this solution has its own detrimental results. See text and note at note 152 supra; United States v. Chappell Livestock Auction, Inc., 523 F.2d 840, 842 n.2 (8th Cir. 1975); Note, Rules of Decision in Nondiversity Suits, 69 YALE L.J. 1428, 144446 (1960). 
rule of decision. The proposed test is designed to overcome the analytical deficiencies apparent in the case law and to yield results more consistent with the purpose of the adoption option. The net result of using the proposed test would be to encourage wider use of state law in connection with governmental activities than is generally allowed under current adoption decisions. By stressing the need for a direct conflict before adoption can be automatically precluded, the proposed test demands an analysis of the specific purposes of the federal program involved and of the impact state law would have on these purposes. General arguments concerning interference with federal interests will be given little weight in the adoption decision. The proposed test also decreases the emphasis given to arguments invoking a generalized need for uniformity and requires critical analysis of the actual interests underlying need for uniformity arguments. Finally, the test broadens the category of state interests which may be weighed in the balancing process to include impacts on state regulation outside areas of traditionally local concern. Applying the proposed test to the FmHA cases illustrates that the test can accomplish the purpose of accommodating the state and federal interests involved in the implementation of a federal program more consistently and effectively than the approaches now used by the courts. Under the proposed test, the suggestion in Clearfield that courts may choose state law to determine the content of federal rules can and should be followed more frequently.

Theresa C. O'Loughlin 